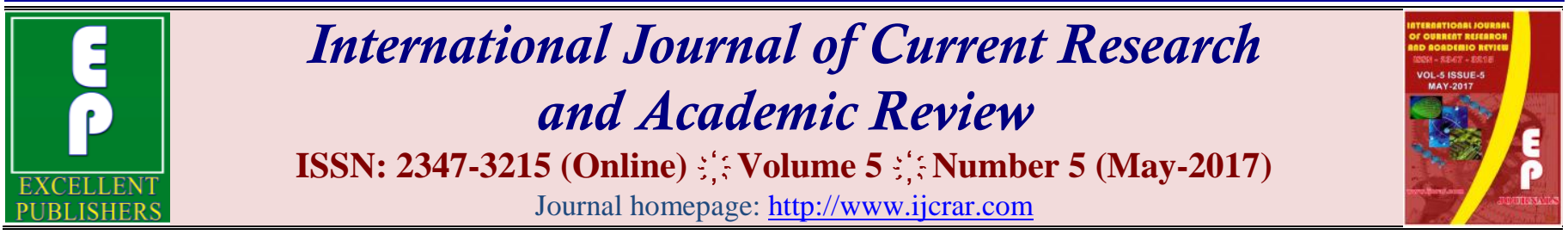

doi: https://doi.org/10.20546/ijcrar.2017.505.008

\title{
Tillage Crop Establishment and Organic Inputs with Kappaphycus - Sap Effect on Soil Organic Carbon Fractions and Water Footprints under a Six Year Rice-Wheat Rotation
}

\author{
R.K. Naresh ${ }^{1 *}$, Arup Ghosh ${ }^{2}$, Vivak Kumar ${ }^{3}$, R.K. Gupta ${ }^{4}$, S.P. Singh ${ }^{5}$, Purushottam ${ }^{6}$, Vineet \\ Kumar $^{7}$, Saurab Tyagi ${ }^{1}$, Vikrant Singh ${ }^{8}$, Nihal Chandra Mahajan ${ }^{1}$, Arun Kumar ${ }^{1}$ and Onkar Singh ${ }^{5}$
}

${ }^{1}$ Department of Agronomy; ${ }^{3}$ Department of Agricultural Engineering; ${ }^{5}$ Department of Soil Science; ${ }^{6}$ Department of Microbiology and Pathology Sardar Vallabhbhai Patel University of Agriculture \& Technology, Meerut-250110, U.P., India

${ }^{2}$ Central Salt and Marine Research Institute, G.B. Marg, Bhavnagar - 364 002, Gujarat (CSMCRI), India

${ }^{4}$ Borlaug Institute for South Asia (BISA), New Delhi -110 012, India

${ }^{7}$ Indian Institute of Farming System Research Modipuram-250110, Meerut, U.P., India

${ }^{8}$ Directorate of Sugarcane Development, Aliganj, Lucknow- 226024 (U.P.), India

*Corresponding author:

\begin{abstract}
An understanding of the dynamics of soil organic carbon (SOC) as affected by farming practices is imperative for maintaining soil productivity. The objective of this study was to assess the effect of tillage systems and inorganic inputs with $K$ sap on the changes in SOC under rice - wheat rotation in western IGP. Results showed that ZT increased soil bulk density in the $0-20 \mathrm{~cm}$ soil layer. Adoption of ZT and PRB increased the concentrations of SOC and TC at $0-15 \mathrm{~cm}$ depth but decreased the concentrations in deeper soil. The greatest SOC and TC concentrations were observed under ZT at $0-15 \mathrm{~cm}$ depth and under PRB at $15-30 \mathrm{~cm}$ depth. Adoption of ZT farming enhanced the SOC and TC stocks in the $0-15 \mathrm{~cm}$ layer, whereas PRB increased SOC and TC stocks in the $15-30 \mathrm{~cm}$ profile. The stratification ratio (SR) of the SOC and TC concentrations was larger under ZT compared with PRB and CT. Thus, the adoption of short-term (5-6 years) ZT practices is beneficial for the enhancement of SOC and TC stocks in the $0-15 \mathrm{~cm}$ soil profile, and rotational tillage may be an appropriate farming practice for rice- wheat system. Application of NPK either through inorganic fertilizers or through combination of inorganic fertilizer and organics such as farm yard manure (FYM) with k sap improved the SOC, particulate organic carbon (POC), microbial biomass carbon (MBC) concentration and their sequestration rate. Application of $75 \% \mathrm{RDF}+25 \% \mathrm{~N}$ through FYM with k sap in rice wheat rotation sequestered $0.39,0.50,0.51$ and $0.62 \mathrm{Mg} \mathrm{C} \mathrm{ha}^{-1} \mathrm{yr}^{-1}$ over control, respectively. SOC with response to application of fertilizer partially substituted $(25 \%$ on $\mathrm{N}$ basis) with organics was higher in $15 \% \mathrm{k}$ sap. The rice water foot print recorded a significant declining trend in RDF plots where as the water foot print trend was stable at $\mathrm{RDF}+\mathrm{FYM}$ plots and lower value under unfertilized control. The water productivity in RDF fertilized plots and RDF+FYM with k sap showed either an increasing trend or remained stable at all treatments during six years of the experiment.
\end{abstract}

Article Info

Accepted: 05 May 2017

Available Online: 20 May 2017

\section{Keywords}

K-sap, Water footprints, Soil organic carbon, Microbial biomass carbon. 


\section{Introduction}

Following the unprecedented expansion and intensification of agriculture in India, there is clear evidence of a decline in the soil organic carbon (SOC) contents in many soils as a consequence; while on the other hand it has been reported that good farming practices such as balanced fertilization and addition of crop residues either maintains or results build up or depletion of SOC stock (Kong et al., 2005). The benefits of soil organic carbon are linked closely to the fact that it acts as a storehouse for nutrients, is a source of soil fertility, and contributes to soil aeration, thereby reducing soil compaction. Other benefits are related to the improvement of infiltration rates and the increase in storage capacity for water. Furthermore, it acts as an energy source for soil microorganisms. Irrespective of its potential benefits to productivity and profitability, organic carbon might be sequestered by vegetation and soils, as a possible way of reducing the rate of $\mathrm{CO}_{2}$ enrichment of atmosphere and moderate the global climate change. The potential of agriculture (excluding bioenergy) to absorb large quantities of atmospheric $\mathrm{CO}_{2}$ through soil carbon sequestration which has strong synergy with sustainable agriculture is widely being put forward as one of the mitigating options for climate change (Post et al., 2004). Thus, one of the more promising ways to reduce the rate of rise in atmospheric $\mathrm{CO}_{2}$ is to encourage management policies that promote $\mathrm{C}$ sequestration in vegetation and ultimately in soils (Idso and Idso, 2002). The SOC concentration of most soils in India is less than $10 \mathrm{~g} \mathrm{~kg}^{-1}$, and is generally less than $5 \mathrm{~g} \mathrm{~kg}^{-1}$. Because of the low clay contents, the SOC concentration is especially low in alluvial soils of the Indo-Gangetic Plains (IGP) and arid zone soils of northwestern India (Dhir et al., 1991). These soils have been cultivated for centuries, and often with low off-farm input, based on systems that involve removal of crop residue and dung for fuel and other purposes. Consequently, SOC concentration of most soils is low. The prevalent low levels of SOC concentrations are attributed to soil-mining practices of excessive tillage, imbalance in fertilizer use, little or no crop residue returned to the soil, and soil degradation (Lal, 2004b). The most agricultural soils can store more carbon and even a modest increase in carbon stocks across the large land areas used for agriculture would represent a significant GHG mitigation by decreasing the rate of enrichment of atmospheric $\mathrm{CO}_{2}$. Nevertheless there are much uncertainty and debate on the total potential of soils to store additional carbon, the rate at which soils can store carbon, the permanence of this carbon sink, and how best to monitor changes in soil carbon stocks (Sanderman et al., 2010). Seaweed Liquid Fertilizer (SLF) is a blend of both plant growth regulators and organic nutrient input is eco-friendly, promoting sustainable productivity and maintaining soil health (Mohanty et al., 2013). Recent researches proved that seaweed fertilizers are preferred not only due to their nitrogen, phosphorus and potash content but also because of the presence of high amount of water soluble potash (Mondal 2013). It also contains all the trace elements and plant growth hormones required by plant to enhance yield attributes (Latique et al., 2013). Seaweed liquid fertilizer contains micro and macro nutrient and growth promoters (Prasad et al., 2010). Several other mineral and trace elements are also reported to be present in seaweed, which are readily absorbed by plant and they control nutrient deficiency in the plants. Many researchers proved that the foliar application of Kappaphycus alvarezii (Shah et al., 2013; Mondal et al., 2015) and Gracilaria edulis (Dwivedi et al., 2014; Layek et al., 2015) improved productivity and quality of crop without impairing the soil fertility.Crop cultivation using organic fertilizers has contributed for deposition of residues, improving physical and chemical properties of soil that is important for biological development (Pramanick et al., 2014).

Several field researches in this region (Malik et al. 2014; Ghatala et al., 2013) urged the need of alternative ways for rebuilding soil organic matter on Indo- Gangetic Plains. Conservation tillage and crop residue management are suggested as suitable practices to decrease soil bulk density and increase infiltration capacity (Naresh et al. 2015) as well as to promote aggregate stability and soil organic carbon (Six et al. 2002). Furthermore, much of the tillage experiment results suggest that SOC is influenced by typical research conditions in each locality. These diverse research findings in different agro-ecosystems motivated us to contribute to tillage and residue literature pertaining to SOC sequestration in a relatively less explored rice-growing pocket area of western Uttar Pradesh. The existing literature related to the rational water management for optimum yield with the benefit of conservation tillage with crop residue and $\mathrm{K}$ sap application is also not clear. Results from this field-scale study are the first estimates providing a site-specific SOC stock data for the dominant rice-wheat cropping system useful for national level carbon database development program of India. On this background, the 
objectives of this study were to evaluate the effects of tillage, crop residue, and $\mathrm{K}$ sap on SOC sequestration under rice-wheat crop rotation system in western Uttar Pradesh.

\section{Materials and Methods}

\section{Experimental site}

The field experiment was established in 2010 at Sardar Vallabhbhai Patel University of Agriculture \&Technology, Meerut research farm $\left(29^{0} 04^{\prime}, \mathrm{N}\right.$ latitude and $77^{\circ} 42^{\prime}$ ' $E$ longitude a height of $237 \mathrm{~m}$ above mean sea level) U.P., India. The region has a semi-arid subtropical climate with an average annual temperature of $16.8^{0} \mathrm{C}$. The highest mean monthly temperature $\left(38.9^{\circ} \mathrm{C}\right)$ is recorded in May, and the lowest mean monthly temperature $\left(4.5^{\circ} \mathrm{C}\right)$ is recorded in January. The average annual rainfall is about 665 to $726 \mathrm{~mm}$ (constituting $44 \%$ of pan evaporation) of which about $80 \%$ is received during the monsoon period. The predominant soil at the experimental site is classified as Typic Ustochrept. Soil samples for 0-20 cm depth at the site were collected and tested prior to applying treatments and the basic properties were non-saline (EC $0.42 \mathrm{dS} \mathrm{m}^{-1}$ ) but mild alkaline in reaction ( $\mathrm{pH} 7.98)$. The soil initially had 4.1 $\mathrm{g} \mathrm{kg}^{-1}$ of SOC and $1.29 \mathrm{~g} \mathrm{~kg}^{-1}$ of total $\mathrm{N}$ (TN), $1.23 \mathrm{~g} \mathrm{~kg}^{-}$ ${ }^{1}$ of total phosphorus, $17.63 \mathrm{~g} \mathrm{~kg}^{-1}$ of total potassium, $224 \mathrm{mg} \mathrm{kg}^{-1}$ of available $\mathrm{N}, 4.0 \mathrm{mg} \mathrm{kg}{ }^{-1}$ of available phosphorus, and $97 \mathrm{mg} \mathrm{kg}^{-1}$ of available potassium.

\section{Experimental design and management}

A detailed description of different tillage systems is necessary to compare the influence of tillage practices on environmental performance (Derpsch et al., 2014).Seven tillage crop establishment methods $T_{1}$ ZTWR; $\mathrm{T}_{2^{-}}$, ZT RR with 4 tha $^{-1} ; \mathrm{T}_{3^{-}}$ZT RR with 6 tha $^{-1}$; $\mathrm{T}_{4^{-}}$PRBWR, $\mathrm{T}_{5^{-}}$PRB RR with 4 tha $^{-1} ; \mathrm{T}_{6^{-}}$PRB RR with 6 tha $^{-1} ; \mathrm{T}_{7^{-}}$Conventional tillage in main plots and ten nutrient management practices were $\mathrm{F}_{1}$-Control; $\mathrm{F}_{2}$ RDF; $\mathrm{F}_{3}-75 \% \mathrm{RDF}+$ Farmyard manure (FYM 5tha ${ }^{-1}$ ); $\mathrm{F}_{4}-75 \% \quad \mathrm{RDF}+\mathrm{FYM} \quad 5$ tha $^{-1}+5 \% \quad \mathrm{~K}$ sap; $\mathrm{F}_{5^{-}}-75 \%$ RDF+FYM 5tha ${ }^{-1}+10 \% \mathrm{~K}$ sap; $\mathrm{F}_{6}-75 \%$ RDF+FYM 5tha ${ }^{-}$ ${ }^{1}+15 \% \mathrm{~K}$ sap; $\mathrm{F}_{7^{-}} \mathrm{RDF}+\mathrm{FYM} 5$ tha $^{-1}+5 \% \mathrm{~K}$ sap $; \mathrm{F}_{8^{-}}$ RDF+FYM 5 tha $^{-1}+10 \% \mathrm{~K}$ sap; $\mathrm{F}_{9}-\mathrm{RDF}+\mathrm{FYM} 5$ tha $^{-1}$ $+15 \%$ Ksap; $\mathrm{F}_{10^{-}} \mathrm{RDF}+\mathrm{FYM} 5$ tha $^{-1}$ allotted to sub-plots in a split-plot design and replicated thrice. The gross and net plot sizes were $8 \mathrm{~m} \times 3.2 \mathrm{~m}$ and $6.0 \mathrm{~m} \times 2.0 \mathrm{~m}$, respectively and treatments were superimposed in the same plot every year to study the cumulative effect of treatments.
The tillage and crop establishment methods comprised of (i) conventional tillage (CT): In conventional tillage there were four tillage operations. The first tillage was performed in the pre-monsoon season (April/May) and the second one was performed in May/June, some 20-25 days after the first tillage. The third tillage was conducted during June and the fourth rice harvest (October/November) at deeper depth $(>15 \mathrm{~cm})$ using a tractor drawn cultivator. Similar tillage operations were followed for the wheat crop.; (ii) Permanent Raised Beds (FIRB): seeds were drilled, $5 \mathrm{~cm}$ deep, over rice harvested bed tops, in six rows, after superficial reshaping using plots using inclined plate zero-till cum raised bed planter (FIRB); and (iii) zero tillage (ZT): seeds were drilled, $5 \mathrm{~cm}$ deep, on untilled rice harvested plots using inclined plate zero-till seed drill. The residue management consisted of (a) residue retention (RR): The $40 \mathrm{~cm}$ stubbles of preceding crop were left at harvest and chopped rice straw of size $15-20 \mathrm{~cm}$ was applied in 4 tha $^{-1}$ and $6 \mathrm{tha}^{-1}$ as mulch manually on the same day after sowing of wheat in each year. (b) Residue removal (RO): preceding crop was harvested from ground level leaving about $5 \mathrm{~cm}$ stubbles. The nutrient management practices one-third of $\mathrm{N}$ and entire $\mathrm{P}, \mathrm{K}$ were applied at the time of transplanting/sowing and remaining $\mathrm{N}$ was top dressed in 2 equal splits at maximum tillering and panicle/ear emergence. The FYM was incorporated in the soil one week before transplanting/sowing of the crops. Both crops were grown under assured irrigated conditions with recommended agronomic practices.

\section{Soil sampling and processing}

Soil samples from each replicated plot were collected randomly from three spots with the help of a core sampler (10 cm internal diameter and $15 \mathrm{~cm}$ height) after the harvest of wheat crop in the year 2009. The soil cores were collected from 0 to 15,15 to 30,30 to 45 and 45 to $60 \mathrm{~cm}$ soil depth. One composite sample representing each replication was prepared by mixing two cores of respective soil depth. Immediately after collection, the soil samples were brought to the laboratory and stored in a refrigerator for measurement of cumulative carbon mineralized $\left(\mathrm{C}_{\min }\right)$ and microbial biomass carbon (MBC). A subset of soil samples was air dried and passed through a $2 \mathrm{~mm}$ sieve for determination of $\mathrm{pH}$, SOC and particulate organic carbon (POC). The third core sample was used for the estimation of bulk density. The soil porosity was computed from the relationship between bulk density and particle density using (1). Soil field capacity and permanent wilting 
point were measured using pressure plate apparatus [Black, 1965].

Porosity (\%) $\quad=\quad 1-\frac{\mathrm{BD}}{P D} \times 100$

(1)

\section{Separation of soil aggregates}

Aggregate-size separation was performed using a wet sieving method (Elliott, 1986). Soil samples (100-g airdried $<5 \mathrm{~mm}$ ) were placed on top of a $2.0 \mathrm{~mm}$ sieve and submerged for $5 \mathrm{~min}$ in deionized water, to allow slaking (Kemper and Rosenau, 1986). Sieving was performed mechanically moving the sieve up and down $3 \mathrm{~cm}, 50$ times in 2 min using a modified Yoder's apparatus. A series of five sieves $(2,1,0.5,0.25$ and $0.11 \mathrm{~mm}$ ) was used to obtain six aggregate fractions (i) $>2$ (Very large macro-aggregates), (ii) 2-1(large macroaggregates), (iii) 1-0.5 (medium macro-aggregates), (iv) 0.5-0.25 (small macro-aggregates) ,(v) 0.25-0.0.106 (micro-aggregates), and (vi) $<0.106$ (silt- and clay-sized particles).

\section{Soil analysis}

The soil $\mathrm{pH}$ was measured in soil: water suspension $(1: 2)$. The electrical conductivity $\left(\mathrm{E}_{\mathrm{Ce}}\right)$ was determined in soil saturation extract. The bulk density of soil was measured using core sampler method as suggested by Veihmeyer and Hendrickson (1948).

\section{Soil organic carbon}

Soil organic carbon was determined by wet digestion with potassium dichromate along with $3: 2 \mathrm{H}_{2} \mathrm{SO}_{4}: 85 \%$ $\mathrm{H}_{3} \mathrm{PO}_{4}$ digestion mixture in a digestion block set at $120^{\circ} \mathrm{C}$ for $2 \mathrm{~h}$ (Snyder and Trofymow, 1984).A pretreatment with $3 \mathrm{ml}$ of $1 \mathrm{NHCl} \mathrm{g}^{-1}$ of soil was used for removal of carbonate and bicarbonate. By using the bulk density value the SOC for each soil layer was calculated and expressed as $\mathrm{Mg} \mathrm{ha}{ }^{-1}$.

\section{Particulate organic carbon}

Particulate organic matter (POM) was separated from 2 $\mathrm{mm}$ soil following the method described by Camberdella and Elliott (1992). Briefly a $10 \mathrm{~g}$ sub-sample of soil was dispersed in $100 \mathrm{ml} 0.5 \%$ sodium hexa-metaphosphate solution by shaking for $15 \mathrm{~h}$ on a reciprocal shaker. The soil suspension was poured over a $0.05 \mathrm{~mm}$ screen. All material remaining on the screen, defined as the particulate organic fraction within a sand matrix, was transferred to a glass beaker and weighed after ovendrying at $60^{\circ} \mathrm{C}$ for $24 \mathrm{~h}$. The particulate organic carbon in POM was determined following the method of Snyder and Trofymow (1984).

\section{Water soluble organic carbon}

The water soluble organic carbon (WSOC) was successively analyzed according to the method described by Zhang et al. (2010). Briefly, the soil samples were first suspended in distilled water at $70 \pm 1^{\circ} \mathrm{C}$ for $60 \mathrm{~min}$. The supernatant was referred to as the water soluble fraction (WSF)

\section{Black carbon}

Black carbon (BC) was analyzed by the method given by Aiken et al. (1985). Soil samples were reacted with $25 \mathrm{ml}$ of $01 \mathrm{~mol} \mathrm{~L}^{-1} \mathrm{~K}_{2} \mathrm{Cr}_{2} \mathrm{O}_{7}+2 \mathrm{~mol} \mathrm{~L}^{-1} \mathrm{H}_{2} \mathrm{SO}_{4}$ solution at $55 \pm 1^{\circ} \mathrm{C}$ for $60 \mathrm{~h}$, and the oxidized organic $\mathrm{C}$ was determined by titration using $0.2 \mathrm{~mol} \mathrm{~L}^{-1} \mathrm{FeSO}_{4}$ solution. The content of $\mathrm{BC}$ was calculated by subtracting the oxidized organic carbon from the TOC.

\section{Soil microbial biomass carbon}

For the estimation of soil microbial biomass $\mathrm{C}$ and $\mathrm{N}$ by the chloroform fumigation and incubation method (Horwath and Paul, 1994), the soil moisture was adjusted to $55 \%$ field water capacity, pre-incubated at $25^{\circ} \mathrm{C}$ for 7 days in the dark, and each soil sample was subdivided into two subsamples for fumigated and nonfumigated treatments. For MBC, soil samples, equivalent to $30 \mathrm{~g}$ dry weight, were fumigated with $\mathrm{CHCl}_{3}$ for $24 \mathrm{~h}$ at $25^{\circ} \mathrm{C}$.After removing the $\mathrm{CHCl}_{3}$, each soil sample was incubated at $25^{\circ} \mathrm{C}$ for a period of 10 days in closed tight Mason jar along with vials containing $1.0 \mathrm{ml} 2 \mathrm{M} \mathrm{NaOH}$. The flush of $\mathrm{CO}_{2}-\mathrm{C}$ released upon fumigation was determined from titration with $\mathrm{HCl}$.

The MBC was computed using Eq. (2):

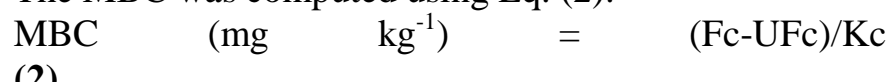

Where,

$\mathrm{Fc}$ is $\mathrm{CO}_{2}$ evolved from the fumigated soil, $\mathrm{UFc}$ is $\mathrm{CO}_{2}$ evolved from the unfumigated soil, and 
$\mathrm{Kc}$ is a factor with value of 0.41 Anderson and Domsch, (1978).

For MBN, fumigated and non-fumigated soil samples after 10-day incubation were extracted with $2 \mathrm{M} \mathrm{KCl}$ (5:1 ratio of extractant: soil) for $1 \mathrm{~h}$ and inorganic $\mathrm{N}$ was determined by the Kjeldahl distillation as described by Keeney and Nelson (1982). The MBN was computed using Eq. (3):

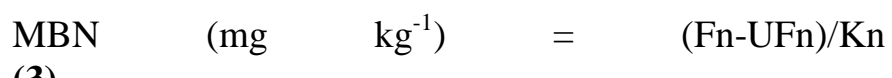

Where,

Fn is mineral $\mathrm{N}$ from fumigated soil,

UFn is mineral $\mathrm{N}$ from unfumigated soil, and

$\mathrm{Kn}$ is a factor with value of 0.57 Jekinson, (1988).

\section{Water footprints and water productivity}

Water footprint (WFP) is expressed as the volume of water consumed or evaporated and/or polluted to grow a crop per unit mass of its economic yield, usually the unit is expressed as $\mathrm{m}^{3} \mathrm{t}^{-1}$ or liters $\mathrm{kg}^{-1}$ (Hoekstra and Chapagain 2008).

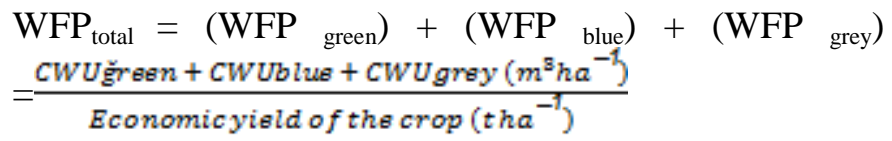

Field level water footprints of RWCS under different nutrient management practices

Total crop water demand for the rice-wheat cultivation is the water required for crop evapo-transpiration, seepage and percolation during crop growth period and water needed for evaporation and percolation during land preparation. Since water footprint refers to a real loss to the catchment, only crop evapo-transpiration and evaporation during land preparation were considered for WFP calculation. Thus, the WFP $\left(\mathrm{m}^{3} \mathrm{t}^{-1}\right)$ of rice -wheat production is the sum of the volume of evaporates per unit quantity of yield production. Since, percolation is actually not a loss to the catchment, therefore, this loss during crop growth period and land preparation was not included for farm level water footprint computation. But the grey WF of the crop due to $\mathrm{N}$ pollution was computed and was added with green and blue WF to determine total WF.

\section{Statistical analysis}

Statistical analysis was performed by the Windowsbased SPSS program (Version 10.0, SPSS, 1996, Chicago, IL). The SPSS procedure was used for analysis of variance to determine the statistical significance of treatment effects. Duncan's Multiple Range Test (DMRT) was used to compare means through least significant difference (LSD). The 5.0\% probability level is regarded as statistically significant.

\section{Results and Discussion}

\section{Changes of soil physical properties}

\section{Bulk density and porosity}

Among tillage and crop establishment methods, plots under zero till without residue $\mathrm{T}_{2}$ had about 5\% higher soil bulk density $\left(1.62 \mathrm{gm}^{-3}\right)$ than $\mathrm{T}_{7}$ plots (Table 1).Unlike residue management, tillage had greater impacts on soil bulk density. Plots under $\mathrm{T}_{3}$ and $\mathrm{T}_{5}$ had $\sim 7 \%$ less soil bulk density as compared with $\mathrm{T}_{7}$ treated plots (Table 1). The bulk density did varied significantly due to planting techniques and it was significantly reduced under raised bed planting compared to flat sowing. This was attributed mainly due to more pore spaces created in the beds through modified land configuration by accumulations the topsoil.

The field capacity (FC) was also increased due to different tillage practices. The highest field capacity increase $(12.5 \%)$ was found in $\mathrm{T}_{1}$ followed by $\mathrm{T}_{5}$. After four years treatment $T_{7}$ showed the lowest increase of field capacity value (Table 1). Permanent wilting point (PWP) was also influenced by the different tillage practices. After four years, the permanent wilting point was decreased due to tillage practices (Table 1). The highest reduction $(8.3 \%)$ was found in raised beds configuration followed by $\mathrm{CT}(7.8 \%)$ and the lowest reduction $(7.5 \%)$ in ZT. Soil porosity results showed that the residue retention treatments $\left(T_{2}, T_{3}\right.$ and $\left.T_{5}\right)$ could increase the total porosity of soil, while zero tillage without residue $\left(T_{2}\right)$ would decrease the soil porosity for aeration as a result; it enhances the water holding capacity of soil along with bad aeration of soil. However, the effects of tillage and residue retention treatments $\left(\mathrm{T}_{3}\right.$ and $\left.\mathrm{T}_{5}\right)$ on the total porosity and porosity size distribution were not significant and zero tillage 
without residue $\left(T_{2}\right)$ could increase the quantity of big porosity.

\section{Cation exchange capacity}

Other notable changes in soil quality due to the legacy of residue harvesting are evident in (Table 1). Cation exchange capacity (CEC) was also increased due to tillage crop establishment. The highest CEC increase $(10.3 \%)$ was found in $\mathrm{T}_{1}$ followed by $\mathrm{T}_{5}(4.2 \%)$ and $\mathrm{T}_{3}$ (1.4\%). Treatment $\mathrm{T}_{7}$ showed the lowest increase of CEC from the experimentation (Table 1).The large loss of aggregate stability for the zero-till system is of particular concern, as it suggests that the increased aggregate stability of surface soil under no-till is due to surface residue rather than an intrinsic property of zerotillage.

\section{Basal respiration}

Basal respiration was generally lower for soil samples from plots where residue was removal; although there were inconsistencies in the results as basal respiration of the zero tillage, wide raised beds and conventional plow systems appeared to increase with residue removal (Table 1). This observation is consistent with that of Hammerbeck et al., (2012).

\section{Aggregate-size distribution}

Aggregate size distribution in different soil depths were significantly impacted by management practices (Table 2). Macro aggregates accounted for $>51 \%$ of total aggregates. In topsoil $(0-10 \mathrm{~cm}$ soil layer), these were the dominant water-stable aggregates (WSA). Significantly higher (60\%) water-stable macroaggregates were recorded in PRB plots compared with $\mathrm{CT}$ in the topsoil, with a concurrent decrease in micro aggregates in the ZT plots. A similar trend also was recorded in sub-surface soil (Table 2). Small macroaggregates were the greatest proportion of the whole soil, followed by aggregates $<0.106 \mathrm{~mm}$ in topsoil. Plots under PRB had significantly more large and small micro-aggregates than ZT plots in $0-10$ and $10-20 \mathrm{~cm}$ soil layers. The PRB plots had significantly more large macro-aggregates, with a concomitant decrease in 'silt + clay' sized aggregates $(<0.106 \mathrm{~mm})$ compared with ZT plots in the topsoil.

In the sub-surface soil, size distributions of aggregates were also significantly influenced by tillage, practices.
Small macro-aggregates comprised the greatest proportion of the whole soil, followed by aggregates $<0.106 \mathrm{~mm}$ in the $10-20 \mathrm{~cm}$ soil layer. Subsurface soil (10-20 cm depth) had 34\% higher macro-aggregates than micro-aggregates (Table 2). The percentage of water-stable aggregates of the largest size class $(>2 \mathrm{~mm})$ in PRB plots at depth of 0 to 10,10 to 20 , and 20 to 30 $\mathrm{cm}$ was approximately twice the percentage under CT but significant only below the $10-\mathrm{cm}$ soil layer. The comparison between $\mathrm{ZT}$ and $\mathrm{CT}$ did not produce significant results until a depth of $20 \mathrm{~cm}$. In contrast, the soil in all layers of the CT treatment had the highest percentage of water-stable aggregates of the smallest size class $(<0.106 \mathrm{~mm})$ compared with both the PRB and ZT treatments. Aggregate data revealed that the macroaggregates increased by $39 \%$ and micro-aggregates decreased by $9 \%$ in PRB plots compared with CT plots. Decrease in micro-aggregates and increase in macroaggregates with application of conservation tillage might have enhanced soil aggregation processes.

\section{Soil chemical properties}

\section{Total soil carbon (TC), Soil organic carbon (SOC) and Oxidizable organic carbon $(\mathrm{OC})$}

Resource conservation practices significantly influenced the TC, SOC and OC content of the $0-15 \mathrm{~cm}$ soil layer (Table 3). PRBRR (permanent raised beds with residue retention) $\left(\mathrm{T}_{6}\right)$ and ZTRR (zero till with residue retention) $\left(\mathrm{T}_{3}\right)$ showed significantly higher TC, SOC and OC content of 12.33 and $11.98 \mathrm{~g} \mathrm{~kg}^{-1}$, respectively (Table 3) as compared to the other treatments. Irrespective of residue retention, transplanted rice in zero till plots enhanced $36.7 \%, 38.2 \%$ and $30.6 \%$ of TC, SOC and OC, respectively, in surface soil as compared to conventional tillage with transplanted rice cultivation. Simultaneously, residue retention in permanent raised beds caused an increment of $23.2 \%, 26.1 \%$ and $13.4 \%$ in TC, SOC and OC, respectively over the treatments with no residue management. Similar increasing trends of conservation practices on different forms of carbon under sub-surface $(15-30 \mathrm{~cm})$ soil were observed however, the magnitude was relatively lower (Table 3 ). Results of this work show that the ZT and PRB system with residue retention conserved and increased SOC compared to the (CT), respectively. Less carbon sequestration in bed planting than zero tillage in same level of residue retention in this cropping system might be due to earlier dryness, less microbial population and less decomposition in bed during wheat season. The 
variation of SOC sequestration also depends on difference in microbial populace, moisture and temperature fluctuation (Govaerts et al., 2009).

SOC was found stratified along the soil depth. A higher SOC was found in surface soil decreasing with depth (Table 3). At the $0-15 \mathrm{~cm}$, SOC content under $\mathrm{RDF}+\mathrm{FYM}+5 \% \mathrm{~K}$ sap, $\mathrm{RDF}+\mathrm{FYM}+10 \% \mathrm{~K}$ sap and $\mathrm{RDF}+\mathrm{FYM}+15 \% \mathrm{~K}$ sap were 27,30 and $34 \%$ greater than under control unfertilized plots, respectively. In 15$30 \mathrm{~cm}$ soil layer, $\mathrm{RDF}+\mathrm{FYM}+15 \% \mathrm{k}$ sap had maximum SOC which was significantly higher than all other treatments except RDF+FYM+10\% K sap treatment. In this study, the combination of organic and inorganic fertilization with $\mathrm{k}$ sap enhanced the accumulation of SOC which is consistent with many other studies (Majumder et al., 2008; Banger et al., 2009).

\section{Particulate organic carbon (POC)}

Particulate organic $\mathrm{C}$ was found stratified along the soil depth. A higher POC was found in surface soil decreasing with depth (Table 3). At the 0-15 and 15-30 $\mathrm{cm}$, POC content under ZT and PRB with residue retention was greater than under without residue retention plots and conventional planting, respectively. The decrease in the disruption of soil macro-aggregates under ZT plots permitted a greater accumulation of SOC between and within the aggregates. Thus, less soil disturbance is the major cause of higher POC in the ZT and PRB plots compared with the CT plots in the 0$15 \mathrm{~cm}$ and $15-30 \mathrm{~cm}$ soil layer. This phenomenon might lead to micro-aggregate formation within macroaggregates formed around fine intra-aggregate POC and to a long-term stabilization of SOC occluded within these micro-aggregates. Because increased POC is regarded as a potential indicator of increased $\mathrm{C}$ accumulation (Six et al., 1999), the results of this study indicate that ZT and PRB had a significant effect on the formation and stabilization of SOM within the 0- to 15$\mathrm{cm}$ soil layer and the soil amended by FYM with k sap contained significantly higher POC in the $0-15 \mathrm{~cm}$ than that in the inorganic fertilizer treatments after $6 \mathrm{yrs}$ of cropping in the Northern India. The differences in POC under the tested fertilization regimes can be attributed to differences in the associated inputs of organic materials into the soil, the main sources of POC (depending on the treatment) being the residual root and stubble biomass, crop straw, animal manure and microbial biomass debris. At the 0-15 cm, POC content under $\left(\mathrm{F}_{7}\right)$ $\mathrm{RDF}+\mathrm{FYM}+5 \% \mathrm{k}$ sap, $\left(\mathrm{F}_{8}\right) \mathrm{RDF}+\mathrm{FYM}+10 \% \mathrm{k}$ sap and
$\left(\mathrm{F}_{9}\right) \mathrm{RDF}+\mathrm{FYM}+15 \% \mathrm{k}$ sap were 77,84 and $90 \%$ greater than under control unfertilized plots, respectively. In $15-30 \mathrm{~cm}$ soil layer, $\left(\mathrm{F}_{9}\right) \mathrm{RDF}+\mathrm{FYM}+15 \% \mathrm{k}$ sap had maximum $P O C$ which was significantly higher than all other treatments except $F_{7}$ and $F_{8}$ treatments. The $F_{1}$ (control), $\mathrm{F}_{2}(\mathrm{RDF}), \mathrm{F}_{3}\left(75 \% \mathrm{RDF}+\mathrm{FYM} 5\right.$ tha $^{-1}$ ) and $\mathrm{F}_{10}$ $\left(\mathrm{RDF}+\mathrm{FYM} 5\right.$ tha $\left.^{-1}\right)$ treatments resulted in the lowest levels of POC, because they produce the lowest crop yields, while the RDF+FYM 5 tha $^{-1}+\mathrm{k}$ sap treatments resulted in the highest levels, presumably because of the manure additions. Our results in these respects are consistent with those of Yan et al. (2007).

\section{Water soluble organic carbon (WSOC)}

The distribution of soil mass among the size classes of water stable organic carbon (WSOC) was strongly influenced by tillage crop establishment practices in both the soil depths $(0-15$ and $15-30 \mathrm{~cm})$. WSOC was found to be $5.99 \%$ higher in surface soil than in subsurface soil (Table 4). In both the depths, $\mathrm{T}_{6}$ treatment had the highest WSOC as compared to the other treatments studied. Compared to CT, PRB and ZT coupled with 6 tha $^{-1}$ residue retention increased $22.6 \%$ WSOC in surface soil and $21.9 \%$ in sub surface soil. Among all the treatments, $\mathrm{T}_{6}$ had significantly higher $(15.21 \%)$ proportion of WSOC than the other treatments compared. Irrespective of tillage practices, residue retention resulted in $22.87 \%$ and $16.26 \%$ higher WSOC as compared to the non-residue treatments in surface and sub-surface soil, respectively.

The WSOC content in surface soil $(0-15 \mathrm{~cm})$ was significantly higher in RDF+FYM 5 tha $^{-1}+15 \% \mathrm{k}$ sap $\left(\mathrm{F}_{9}\right)$ treatment $\left(32.4 \mathrm{gkg}^{-1}\right)$ followed by RDF+FYM 5tha ${ }^{1}+10 \% \mathrm{k}$ sap $\left(\mathrm{F}_{8}\right)\left(29.2 \mathrm{gkg}^{-1}\right), \mathrm{RDF}+\mathrm{FYM} 5 \mathrm{tha}^{-1}+5 \% \mathrm{k}$ $\operatorname{sap}\left(\mathrm{F}_{7}\right)\left(27.2 \mathrm{gkg}^{-1}\right)$ and least in unfertilized control plot $\left[\left(\mathrm{F}_{1}\right) \quad\left(16.7 \mathrm{gkg}^{-1}\right) \quad(\right.$ Table 4$\left.)\right]$. However, similar significant effect was observed in sub-surface soil (15$30 \mathrm{~cm}$ ) and the magnitude was relatively lower. The increase in WSOC in $0-15 \mathrm{~cm}$ soil depth was 48.5 and $42.8 \%$ in $\mathrm{RDF}+\mathrm{FYM} 5$ tha $^{-1}+15 \% \mathrm{k}$ sap $\left(\mathrm{F}_{9}\right)$ and RDF+FYM 5 tha $^{-1}+10 \% \mathrm{k}$ sap $\left(\mathrm{F}_{8}\right)$ treated plots over control $\left(\mathrm{F}_{1}\right)$. This increase is attributed to the accretion of sulphur through FYM/ K sap application. Our results are in agreement with Yagi et al. (2005), who attributed the increase of WSOC to the priming effect of the application of fertilizers or fresh organic material to the soil, which stimulated the mineralization of organic matter through increased microbial activity. 


\section{Black carbon (BC)}

The buildup of BC was strongly influenced by tillage crop establishment practices in both the soil depths $(0$ $15 \mathrm{~cm}$ and $15-30 \mathrm{~cm})$. BC was found to be $4.82 \%$ higher in surface soil than in sub-surface soil (Table 4). In both the depths, $\mathrm{T}_{6}$ treatment had the highest $\mathrm{BC}$ as compared to the other treatments studied. Compared to conventional tillage, PRB and ZT coupled with 6tha ${ }^{-1}$ residue retention increased $31.2 \% \mathrm{BC}$ in surface soil and $26.5 \%$ in sub surface soil. Among all the treatments, $\mathrm{T}_{6}$ had significantly higher $(30.84 \%)$ proportion of $\mathrm{BC}$ than the other treatments compared. Irrespective of tillage practices, residue retention resulted in $33.68 \%$ and $31.15 \%$ higher $\mathrm{BC}$ as compared to the non-residue treatments in surface and sub-surface soil, respectively. The buildup of $\mathrm{BC}$ was greater in the surface layer as compared to the sub surface layer (Table 4). In the surface layer, all the treatments accumulated significantly greater $\mathrm{BC}$ over the control unfertilized plots $\left(\mathrm{F}_{1}\right)$. The $\mathrm{BC}$ was $59 \%$ greater in the organic plus inorganic fertilizers $\left(3.62 \mathrm{gkg}^{-1}\right)$ and $27 \%$ greater in the NPK $\left(2.10 \mathrm{gkg}^{-1}\right)$ over the control treatment $\left(\mathrm{F}_{1}\right)$. A similar trend was observed in the subsurface soil, where the $\mathrm{BC}$ content ranged from $1.05 \mathrm{gkg}^{-1}$ in control to 2.64 $\mathrm{gkg}^{-1}$ in the organic plus inorganic fertilizer treatments. In this study, the $\mathrm{BC}$ concentration in the surface soil layers was higher under ZT and PRB than under CT; this is may be due to the placement of residues near the soil surface. Our result supports other studies that recorded higher BC at the upper layers under ZT ((Wright et al., 2007).

\section{Soil biological properties}

\section{Microbial biomass carbon (MBC)}

Distinct difference of MBC content was observed among different treatments and at both depths $(0-15 \mathrm{~cm}$ and $15-30 \mathrm{~cm}$ ) in a six year rice-wheat system. MBC was found to be $4.72 \%$ higher in surface soil than in subsurface soil (Table 4). In both the depths, $\mathrm{T}_{6}$ treatment had the highest MBC as compared to the other treatments studied. Compared to conventional tillage, PRB and ZT coupled with 6 tha $^{-1}$ residue retention increased $55.4 \% \mathrm{MBC}$ in surface soil and $49.8 \%$ in sub surface soil. Among all the treatments, $\mathrm{T}_{6}$ had significantly higher $(29.96 \%)$ proportion of MBC than the other treatments compared except $\mathrm{T}_{3}$. Irrespective of tillage practices, residue retention resulted in $35.2 \%$ and $31.3 \%$ higher $\mathrm{MBC}$ as compared to the non-residue treatments in surface and sub-surface soil, respectively. The buildup of MBC was greater in the surface layer as compared to the sub surface layer (Table 4). In the surface layer, all the treatments accumulated significantly greater MBC over the control. The MBC was $56 \%$ greater in the integrated with k sap $\left(659 \mathrm{gkg}^{-1}\right)$, $41 \%$ greater in the integrated $\left(487 \mathrm{gkg}^{-1}\right)$ and $8 \%$ greater in the NPK $\left(314 \mathrm{gkg}^{-1}\right)$ over the control treatment $\left(\mathrm{F}_{1}\right)$. A similar trend was observed in the subsurface soil, where the MBC content ranged from $101 \mathrm{gkg}^{-1}$ in control to 301 $\mathrm{gkg}^{-1}$ in integrated with $\mathrm{k}$ sap treatments. Greater MBC in the surface layer can be attributed to the availability of crop residues and incorporation of external organic matter in both the organic and integrated treatments. Similar to our study, Manjaiah and Singh (2001) reported an increase of MBC by a factor of three after a combined application of FYM and mineral $\mathrm{N}$-fertilizer in a semi-arid Cambisol.

\section{Mineralizable organic carbon $\left(\mathrm{C}_{\min }\right)$}

The mineralizable organic carbon $\left(\mathrm{C}_{\mathrm{min}}\right)$ is considered as a useful approach for the characterization of SOC resulting from different soil management practices including cropping systems and application of organic and inorganic sources of nutrients. In the present study, the ZT and PRB plots that received 6 tha $^{-1}$ residue had significantly higher build-up in $\mathrm{C}$ min over without residue $\left(578.5 \mu \mathrm{g} \mathrm{g}^{-1}\right)$ and conventional plots $(507.6 \mu \mathrm{g}$ $\mathrm{g}^{-1}$ ) in the surface soil (Table 4). The increase in buildup in $\mathrm{C}_{\text {min }}$ under ZT and PRB treatments was 43.1 and $27.5 \%$ greater over treatment receiving no residue Table 4. In case of sub-surface soil $(15-30 \mathrm{~cm})$, the build-up in $\mathrm{C}$ min similar increasing trends of conservation practices were observed however, the magnitude was relatively lower (Table 4 ).

Significantly higher $\mathrm{C}_{\min }$ content was recorded in continuous RDF+ FYM+ $\mathrm{k}$ sap applied plots over control at both soil depths in all the treatments (Table 4). The treatments where partial substitution of $\mathrm{N}$ were made from organic sources, significantly higher $\mathrm{C}_{\text {min }}$ was recorded both over RDF treated plots and control at surface soil $(0-15 \mathrm{~cm})$. The higher value of $C_{\text {min }}$ content in the RDF fertilizer plus organic amendments with $\mathrm{k}$ sap treatments may be attributed to the good supply of labile C substrate in those treatments (Majumder et al., 2008). However, partial substitution of $\mathrm{N}$ through either FYM or CR resulted at par $\mathrm{C}_{\text {min }}$ content in the surface soil. At all the treatments RDF $+F Y M+k$ sap recorded significantly higher $\mathrm{C}$ min than NPK $+\mathrm{RDF}$ and $\mathrm{RDF}$ 
alone. The differences in $\mathrm{C}_{\text {min }}$ content among different treatments continually reduced towards lower depth. In our study addition of inorganic $\mathrm{N}$ (25\% of recommended dose) along with these materials enhanced its decomposability. This explain the higher $\mathrm{C}_{\min }$ value in FYM with $\mathrm{k}$ sap treated plots at all the sites and CR treated plots at some sites over RDF treated plots.

\section{Water footprints and water productivity}

Table 5 shows the water footprint and the volume of total percolation water per unit amount of yield under tillage crop establishment and nutrient management practices. The highest total water footprint (TWFP) was observed under $\mathrm{T}_{6}$ with the value being $1525 \mathrm{~m}^{3} \mathrm{t}^{-1}$ whereas, WFs Total of 1597, 1673 and $1779 \mathrm{~m}^{3} \mathrm{t}^{-1}$ were computed under $T_{5}, T_{3}$ and $T_{4}$ treatments, respectively. Among nutrient management practices treatments, highest WFP Total was observed when "control" no fertilizer and only RDF was applied with the values being 2162, $2077 \mathrm{~m}^{3} \mathrm{t}^{-1}$ in $\mathrm{F}_{1}$ and $\mathrm{F}_{2}$ treatments, respectively. On the other hand, the lowest WFP Total of 1821, 1795 and $1706 \mathrm{~m}^{3} \mathrm{t}^{-1}$ was achieved under RDF+FYM with 5,10 and $15 \% \mathrm{~K}$ sap $\left(\mathrm{F}_{7}, \mathrm{~F}_{8}\right.$ and $\left.\mathrm{F}_{9}\right)$. Study revealed that total WFP achieved under $\mathrm{RDF}+\mathrm{FYM}+15 \mathrm{~kg} \% \mathrm{~K}$ sap was statistically at par with the values obtained at $\mathrm{RDF}+\mathrm{FYM}+10 \% \mathrm{~K}$ saps. The WFP of the crop was higher when no or lower doses of fertilizers were applied which might be attributed to low grain yield obtained in nutrients stress plots. The WFP reduced significantly with increased levels of nutrients from control to RDF+ FYM+15 kg\% $\mathrm{K}_{\text {sap }} \mathrm{ha}^{-1}$ due to significant yield enhancement under tillage crop establishment practices. On the other hand, total WFP was significantly lower under zero tillage and furrow irrigated raised beds with residue retention than that of conventional tillage.

The highest volume of total percolation water per unit quantity of yield $\left(\mathrm{m}^{3} \mathrm{t}^{-1}\right)$ was also observed under control when no fertilizer and chemical fertilizer was applied with the values being 1358 and $1297 \mathrm{~m}^{3} \mathrm{t}^{-1}$ under $\mathrm{F}_{1}$ and $\mathrm{F}_{2}$ treatments, respectively. On the other hand, the lowest volume of total percolation water per unit of yield $\left(\mathrm{m}^{3} \mathrm{t}^{-1}\right)$ of 1105,1082 and $1035 \mathrm{~m}^{3} \mathrm{t}^{-1}$ were achieved under RDF+FYM with 5, 10 and $15 \% \mathrm{~K}$ sap ha ${ }^{-1}\left(\mathrm{~F}_{7}, \mathrm{~F}_{8}\right.$ and $F_{9}$ ). The reduction of volume of percolation water with higher doses of fertilizer was attributed to mainly increased grain yield of the crop, whereas, decreased percolation volume under $\mathrm{F}_{8}$ and $\mathrm{F}_{9}$ was mainly due to reduction of duration of standing water. The volume of total water use per unit quantity of yield was higher in $\mathrm{T}_{7}$ $\left(3370 \mathrm{~m}^{3} \mathrm{t}^{-1}\right)$ than that of $\mathrm{T}_{1}\left(3133 \mathrm{~m}^{3} \mathrm{t}^{-1}\right)$ and $\mathrm{T}_{4}(3074$ $\mathrm{m}^{3} \mathrm{t}^{-1}$ ) due to continuous submergence under the former treatment, as a result more percolation was experienced under $\mathrm{T}_{7}$. These infer that the water footprint and volume of percolation water to a large extent was influenced by agricultural management rather than by the agro-climate under which the crop was grown. This provides an opportunity to improve yield and water productivity through different improved agromanagement practices. It is also inferred that optimum application of fertilizer has the potential to enhance the yield and in turn to reduce WFP of rice production under tillage crop establishment treatments.

The water productivity per unit quantity of irrigation water (WP $\mathrm{WRRI}_{\mathrm{I}}$, gross or total crop water demand $\left(\mathrm{WP}_{\mathrm{TCW}}\right)$ and evapo-transpiration $\left(\mathrm{WP}_{\mathrm{ETC}}\right)$ under tillage crop establishment and nutrient management practices were computed and are presented in Table 5. Highest $\mathrm{WP}_{\text {IRRI }}$ was obtained under $\mathrm{T}_{6}\left(0.64 \mathrm{~kg} \mathrm{~m}^{-3}\right)$ followed by $\mathrm{T}_{5}\left(0.61 \mathrm{~kg} \mathrm{~m}^{-3}\right)$ and $\mathrm{T}_{3}\left(0.57 \mathrm{~kg} \mathrm{~m}^{-3}\right)$ tillage crop establishment. Under $\mathrm{T}_{6}$ though yield was 9 per cent less than that of $\mathrm{T}_{7}$ but water productivity per unit of irrigation water was 23 per cent higher under $\mathrm{T}_{6}$ because of production of more yield with less water. The yield difference between $T_{3}$ and $T_{5}$ was not statistically significant however, when we assess water productivity per unit of irrigation water, it showed that under $\mathrm{T}_{5}$ the water productivity was significantly higher than that of $\mathrm{T}_{3}$.

The $\mathrm{WP}_{\text {IRRI }}$ was enhanced when $\mathrm{RDF}+\mathrm{FYM}$ with different levels of $\mathrm{K}$ sap was applied with the values being $0.41,0.47,0.52,0.58,0.61$ and $0.63 \mathrm{~kg} \mathrm{~m}^{-3}$ under $\mathrm{F}_{4}, \mathrm{~F}_{5}, \mathrm{~F}_{6}, \mathrm{~F}_{7}, \mathrm{~F}_{8}$ and $\mathrm{F}_{9}$, respectively. On the other hand, water productivity in terms of total crop water need $\left(\mathrm{WP}_{\mathrm{TCW}}\right)$ was $0.35,0.38$ and $0.40 \mathrm{~kg} \mathrm{~m}^{-3}$ under $\mathrm{T}_{7}, \mathrm{~T}_{1}$ and $\mathrm{T}_{4}$ tillage crop establishment treatments, respectively. Though rice plant needed almost same amount of water for transpiration for all the treatments but water savings come from less evaporation and percolation due to land configuration under $T_{1}$ and $T_{4}$ treatments. As a result $\mathrm{WP}_{\mathrm{TCW}}$ was at par among three tillage crop establishment treatments though yield was significantly lower under $\mathrm{T}_{4}$. The $\mathrm{WP}_{\mathrm{TCW}}$ was gradually increased with increasing doses of $\mathrm{K}$ sap but estimated water productivity was at par between $\mathrm{F}_{8}$ and $\mathrm{F}_{9}$. Similar trend was also observed when water productivity in terms of only evapo-transpiration was estimated (Table $5)$. 
Table.1 Effect of tillage crop establishment on bulk density, cation exchange capacity, total porosity, hydraulic conductivity, field capacity, permanent wilting point, infiltration rate and Basal respiration in RWCS

\begin{tabular}{|c|c|c|c|c|c|c|c|c|c|}
\hline \multirow[t]{2}{*}{ Treatments } & \multirow{2}{*}{$\begin{array}{l}\text { Bulk } \\
\text { density } \\
\left(\mathrm{gcm}^{-3}\right)\end{array}$} & \multirow{2}{*}{$\begin{array}{c}\text { Cation } \\
\text { exchange } \\
\text { capacity } \\
\left(\mathrm{cmol} \mathrm{kg}^{-1}\right)\end{array}$} & \multirow{2}{*}{$\begin{array}{c}\text { Total } \\
\text { porosity } \\
(\%)\end{array}$} & \multirow{2}{*}{$\begin{array}{l}\text { Hydraulic } \\
\text { conductivity } \\
\left(\mathrm{mm} \mathrm{h}^{-1}\right)\end{array}$} & \multicolumn{2}{|c|}{$\begin{array}{c}\text { Field capacity } \\
(\%)\end{array}$} & \multicolumn{2}{|c|}{$\begin{array}{c}\text { Permanent } \\
\text { wilting point (\%) }\end{array}$} & \multirow{2}{*}{$\begin{array}{c}\text { Basal } \\
\text { respiration } \\
\left(\mathrm{mg}^{-1} \mathrm{CO}_{2} \mathrm{C}\right. \\
\left.\mathrm{kg}^{-1} \text { day }^{-1}\right)\end{array}$} \\
\hline & & & & & $0-5$ & $5-20$ & $0-5$ & $5-20 \mathrm{~cm}$ & \\
\hline $\mathrm{T}_{1}$ & 1.62 & 24.40 & 37.98 & 53.5 & 31 & 31 & 11 & 10 & 36.93 \\
\hline $\mathrm{T}_{2}$ & 1.52 & 22.33 & 41.58 & 45.6 & 29 & 30 & 12 & 10 & 32.79 \\
\hline$T_{3}$ & 149 & 22.43 & 51.86 & 43.8 & 29 & 30 & 13 & 11 & 26.12 \\
\hline $\mathrm{T}_{4}$ & 1.46 & 20.87 & 52.36 & 46.3 & 30 & 29 & 11 & 10 & 29.69 \\
\hline$T_{5}$ & 1.45 & 23.04 & 53.01 & 36.6 & 28 & 31 & 12 & 11 & 23.44 \\
\hline$T_{6}$ & 1.44 & 21.89 & 54.25 & 35.3 & 27 & 30 & 12 & 10 & 21.30 \\
\hline$T_{7}$ & 1.54 & 19.86 & 49.74 & 48.5 & 30 & 29 & 09 & 08 & 45.94 \\
\hline
\end{tabular}

Table.2 Soil stable aggregate size classes for conventional tillage (CT), zero-till (ZT), and permanent raised bed (PRB) treatments in the 0 - to $30-\mathrm{cm}$ soil depth in 2015

\begin{tabular}{|c|c|c|c|c|c|c|c|c|c|}
\hline \multirow{3}{*}{$\begin{array}{l}\text { Depth } \\
\text { (cm) }\end{array}$} & \multirow[t]{3}{*}{ Treatment } & \multicolumn{6}{|c|}{ Aggregate size distribution } & \multirow{2}{*}{$\begin{array}{c}\text { Macro- } \\
\text { aggregates } \\
(>0.25 \mathrm{~mm})\end{array}$} & \multirow{2}{*}{$\begin{array}{c}\text { Micro- } \\
\text { aggregates } \\
(<0.25 \mathrm{~mm})\end{array}$} \\
\hline & & $>2 \mathrm{~mm}$ & 2-1 mm & $\begin{array}{c}1-0.5 \\
\mathrm{~mm}\end{array}$ & $\begin{array}{c}0.5-0.25 \\
\mathrm{~mm}\end{array}$ & $\begin{array}{c}\text { 0.25-0.106 } \\
\text { mm }\end{array}$ & $\begin{array}{c}<0.106 \\
\mathrm{Mm} \\
\end{array}$ & & \\
\hline & & & & & & & & & \\
\hline \multirow[t]{3}{*}{ 0-10 } & CT & $2.13^{\mathrm{a}}$ & $4.26^{\mathrm{a}}$ & $5.59^{\mathrm{a}}$ & $5.33^{\mathrm{a}}$ & $13.08^{\mathrm{a}}$ & $66.91^{\mathrm{a}}$ & $19.01^{\mathrm{a}}$ & $79.99^{a}$ \\
\hline & ZT & $5.31^{\mathrm{b}}$ & $6.06^{\mathrm{a}}$ & $5.67^{\mathrm{a}}$ & $17.60^{\mathrm{a}}$ & $35.45^{b}$ & $53.73^{\mathrm{a}}$ & $28.89^{\mathrm{a}}$ & $67.11^{\mathrm{a}}$ \\
\hline & PRB & $6.45^{\mathrm{b}}$ & $9.73^{b}$ & $8.09^{\mathrm{a}}$ & $8.95^{\mathrm{a}}$ & $12.83^{\mathrm{a}}$ & $31.66^{\mathrm{b}}$ & $33.44^{\mathrm{a}}$ & $66.57^{\mathrm{a}}$ \\
\hline \multirow[t]{3}{*}{$10-20$} & CT & $2.90^{\mathrm{a}}$ & $3.57^{\mathrm{a}}$ & $4.17^{\mathrm{a}}$ & $5.53^{\mathrm{a}}$ & $12.34^{\mathrm{a}}$ & $72.08^{a}$ & $15.59^{a}$ & $84.42^{a}$ \\
\hline & ZT & $4.36^{\mathrm{ab}}$ & $5.62^{\mathrm{a}}$ & $5.22^{\mathrm{a}}$ & $20.23^{b}$ & $36.90^{\mathrm{b}}$ & $57.47^{\mathrm{a}}$ & $31.46^{\mathrm{b}}$ & $68.54^{\mathrm{b}}$ \\
\hline & PRB & $6.68^{b}$ & $5.69^{\mathrm{a}}$ & $4.05^{\mathrm{a}}$ & $14.98^{\mathrm{ab}}$ & $11.07^{\mathrm{a}}$ & $27.55^{b}$ & $35.56^{b}$ & $64.44^{b}$ \\
\hline \multirow[t]{3}{*}{$20-30$} & CT & $3.55^{\mathrm{a}}$ & $4.10^{\mathrm{a}}$ & $3.14^{\mathrm{a}}$ & $4.10^{\mathrm{a}}$ & $11.90^{\mathrm{a}}$ & $76.76^{\mathrm{a}}$ & $13.81^{\mathrm{a}}$ & $88.76^{\mathrm{a}}$ \\
\hline & ZT & $4.70^{\mathrm{a}}$ & $4.14^{\mathrm{a}}$ & $3.52^{\mathrm{a}}$ & $8.70^{\mathrm{a}}$ & $21.06^{b}$ & $61.84^{\mathrm{ab}}$ & $17.10^{\mathrm{a}}$ & $82.90^{\mathrm{a}}$ \\
\hline & PRB & $7.82^{\mathrm{a}}$ & $8.55^{\mathrm{b}}$ & $8.43^{\mathrm{b}}$ & $13.96^{\mathrm{b}}$ & $16.36^{\mathrm{ab}}$ & $41.55^{b}$ & $38.89^{b}$ & $61.11^{b}$ \\
\hline \multirow[t]{3}{*}{ 0-30 } & CT & $3.20^{\mathrm{a}}$ & $4.24^{\mathrm{a}}$ & $4.25^{\mathrm{a}}$ & $4.79^{\mathrm{a}}$ & $12.44^{\mathrm{a}}$ & $71.85^{\mathrm{a}}$ & $16.47^{\mathrm{a}}$ & $84.39^{a}$ \\
\hline & ZT & $4.46^{\mathrm{ab}}$ & $4.72^{\mathrm{a}}$ & $4.86^{\mathrm{a}}$ & $14.17^{\mathrm{b}}$ & $31.47^{\mathrm{b}}$ & $52.92^{\mathrm{b}}$ & $28.18^{\mathrm{b}}$ & $71.82^{b}$ \\
\hline & PRB & $6.41^{\mathrm{b}}$ & $7.96^{\mathrm{b}}$ & $7.53^{b}$ & $9.30^{\mathrm{ab}}$ & $13.82^{\mathrm{a}}$ & $40.35^{\mathrm{b}}$ & $31.26^{\mathrm{b}}$ & $68.74^{\mathrm{b}}$ \\
\hline
\end{tabular}

Table.3 Effect of tillage crop establishment and nutrient management practices and on distribution of different forms of carbon in soil

\begin{tabular}{|c|c|c|c|c|c|c|c|c|}
\hline \multirow[t]{2}{*}{ Treatments } & \multicolumn{2}{|c|}{$\begin{array}{l}\text { Total soil carbon } \\
\left(\mathrm{TC}_{\mathrm{gkg}}{ }^{-1}\right)\end{array}$} & \multicolumn{2}{|c|}{$\begin{array}{l}\text { Total soil organic } \\
\text { carbon }\left(\mathrm{SOC} \mathrm{gkg}^{-1}\right)\end{array}$} & \multicolumn{2}{|c|}{$\begin{array}{l}\text { Oxidizable organic } \\
\text { carbon }\left(\mathrm{OC} \mathrm{g} \mathrm{kg}^{-1}\right)\end{array}$} & \multicolumn{2}{|c|}{$\begin{array}{l}\text { Particulate organic } \\
\text { carbon (POC } \mu^{-1} \text { ) }\end{array}$} \\
\hline & $0-15 \mathrm{~cm}$ & $15-30 \mathrm{~cm}$ & $0-15 \mathrm{~cm}$ & $15-30 \mathrm{~cm}$ & $0-15 \mathrm{~cm}$ & $15-30 \mathrm{~cm}$ & $0-15 \mathrm{~cm}$ & $15-30 \mathrm{~cm}$ \\
\hline \multicolumn{9}{|c|}{ Tillage crop establishment } \\
\hline $\mathrm{T}_{1}$ & $9.65^{\mathrm{bc}}$ & $8.22^{b c}$ & $8.36^{\mathrm{cd}}$ & $7.68^{\mathrm{cd}}$ & $7.56^{c}$ & $7.31^{\mathrm{bc}}$ & $725.0^{b}$ & $630.5^{\mathrm{cd}}$ \\
\hline$T_{2}$ & $11.03^{\mathrm{ab}}$ & $9.91^{\mathrm{a}}$ & $10.23^{\mathrm{ab}}$ & $9.05^{\mathrm{ab}}$ & $8.78^{\mathrm{ab}}$ & $8.27^{\mathrm{ab}}$ & $798.5^{b}$ & $681.8^{\mathrm{bc}}$ \\
\hline$T_{3}$ & $12.33^{\mathrm{a}}$ & $10.40^{\mathrm{a}}$ & $11.73^{\mathrm{a}}$ & $10.15^{\mathrm{a}}$ & $9.41^{\mathrm{a}}$ & $9.16^{\mathrm{a}}$ & $916.5^{\mathrm{a}}$ & $790.0^{\mathrm{a}}$ \\
\hline $\mathbf{T}_{4}$ & $8.42^{\mathrm{cd}}$ & $7.81^{\mathrm{c}}$ & $7.18^{\mathrm{de}}$ & $6.75^{\mathrm{de}}$ & $7.13^{\mathrm{c}}$ & $6.82^{\mathrm{ct}}$ & $589.0^{C}$ & $586.1^{\mathrm{d}}$ \\
\hline$T_{5}$ & $9.95^{b}$ & $8.35^{b}$ & $8.75^{\mathrm{bc}}$ & $7.96^{\mathrm{bc}}$ & $7.77^{\mathrm{c}}$ & $7.17^{\mathrm{bc}}$ & $699.6^{\mathrm{bC}}$ & $624.7^{\mathrm{cd}}$ \\
\hline$T_{6}$ & $11.98^{\mathrm{a}}$ & $10.24^{\mathrm{a}}$ & $10.68^{\mathrm{a}}$ & $9.30^{\mathrm{a}}$ & $8.69^{b}$ & $8.05^{\mathrm{ab}}$ & $806.9^{\mathrm{ab}}$ & $732.0^{\mathrm{ab}}$ \\
\hline $\mathrm{T}_{7}$ & $7.39^{d}$ & $6.12^{\mathrm{d}}$ & $6.79^{\mathrm{e}}$ & $5.87^{e}$ & $6.31^{\dagger}$ & $5.84^{\dagger}$ & $435.5^{\mathrm{d}}$ & $342.5^{\mathrm{e}}$ \\
\hline \multicolumn{9}{|c|}{ Nutrient Management Practices } \\
\hline $\mathbf{F}_{1}$ & $7.61^{\dagger}$ & $6.82^{9}$ & $6.92^{\dagger}$ & $5.92^{g}$ & $6.23^{g}$ & $5.58^{n}$ & $481.8^{\mathrm{h}}$ & $222.7^{9}$ \\
\hline$F_{2}$ & $8.36^{\text {ef }}$ & $7.29^{19}$ & $7.05^{\text {ef }}$ & $6.15^{\mathrm{fg}}$ & $6.48^{\mathrm{fg}}$ & $5.97^{\text {gh }}$ & $531.8^{\text {gh }}$ & $280.1^{\mathrm{tg}}$ \\
\hline$F_{3}$ & $8.57^{\text {det }}$ & $7.39^{\text {et }}$ & $7.38^{\mathrm{de}}$ & $6.28^{\mathrm{et}}$ & $6.76^{\mathrm{et}}$ & $6.13^{\mathrm{tg}}$ & $586.8^{\text {tg }}$ & $363.2^{\mathrm{et}}$ \\
\hline$F_{4}$ & $9.28^{\mathrm{de}}$ & $8.73^{\mathrm{d}}$ & $7.85^{\mathrm{C}}$ & $6.71^{\mathrm{cd}}$ & $7.15^{\mathrm{d}}$ & $6.79^{\text {de }}$ & $684.8^{\mathrm{de}}$ & $480.4^{\mathrm{d}}$ \\
\hline$F_{5}$ & $9.57^{\text {cde }}$ & $8.83^{\mathrm{cd}}$ & $7.93^{\mathrm{c}}$ & $6.73^{\mathrm{C}}$ & $7.34^{\mathrm{cd}}$ & $6.90^{\mathrm{d}}$ & $743.1^{\mathrm{cd}}$ & $513.8^{\mathrm{cd}}$ \\
\hline$F_{6}$ & $9.98^{\mathrm{cd}}$ & $8.92^{\mathrm{cd}}$ & $8.50^{b}$ & $6.77^{\mathrm{c}}$ & $7.54^{\mathrm{bc}}$ & $7.10^{\text {cd }}$ & $798.5^{\mathrm{bc}}$ & $585.0^{\mathrm{bc}}$ \\
\hline$F_{7}$ & $10.90^{\mathrm{bc}}$ & $9.87^{\mathrm{bC}}$ & $8.79^{b}$ & $7.98^{b}$ & $7.68^{\mathrm{bc}}$ & $7.38^{\mathrm{bC}}$ & $854.0^{\mathrm{ab}}$ & $655.4^{\mathrm{ab}}$ \\
\hline$F_{8}$ & $11.97^{\mathrm{ab}}$ & $10.93^{\mathrm{ab}}$ & $8.99^{\mathrm{ab}}$ & $8.27^{\text {ab }}$ & $7.89^{\mathrm{ab}}$ & $7.58^{\text {ab }}$ & $888.9^{a}$ & $698.5^{\mathrm{a}}$ \\
\hline$F_{9}$ & $13.56^{\mathrm{a}}$ & $11.98^{\mathrm{a}}$ & $9.30^{\mathrm{a}}$ & $8.57^{\mathrm{a}}$ & $8.21^{a}$ & $7.95^{\mathrm{a}}$ & $916.5^{a}$ & $738.5^{\mathrm{a}}$ \\
\hline$F_{10}$ & $9.24^{\mathrm{de}}$ & $8.48^{\mathrm{de}}$ & $7.64^{\text {cd }}$ & $6.47^{\mathrm{de}}$ & $6.99^{\mathrm{de}}$ & $6.47^{\text {ef }}$ & $632.0^{\text {ef }}$ & $436.8^{\mathrm{de}}$ \\
\hline
\end{tabular}

Different small letters within the same column show the significant difference at $\mathrm{P}=0.05$ according to

Duncan Multiple Range Test for separation of mean.

$\mathrm{TC}=$ Total soil carbon, $\mathrm{SOC}=$ Total soil organic carbon, $\mathrm{OC}=$ Oxidizable organic carbon, $\mathrm{POC}=$ Particulate organic carbon 
Table.4 Effect of tillage and residue management practices on distribution of different forms of carbon in soil

\begin{tabular}{|c|c|c|c|c|c|c|c|c|}
\hline \multirow[t]{2}{*}{ Treatments } & \multicolumn{2}{|c|}{$\begin{array}{l}\text { Water soluble organic } \\
\text { carbon }\left(\text { WSOC } \mathrm{kg}^{-1} \text { ) }\right.\end{array}$} & \multicolumn{2}{|c|}{$\begin{array}{l}\text { Black carbon } \\
\left({\left.\mathrm{BC} \mathrm{gkg}^{-1}\right)}\right.\end{array}$} & \multicolumn{2}{|c|}{$\begin{array}{l}\text { Microbial biomass } \\
\text { carbon }\left(\mathrm{MBC} \mu \mathrm{gg}^{-1}\right)\end{array}$} & \multirow{2}{*}{\multicolumn{2}{|c|}{$\begin{array}{l}\text { Mineralizable carbon } \\
\left(\mathrm{C}_{\min } \mu \mathrm{g} \mathrm{g}^{-1}\right)\end{array}$}} \\
\hline & $0-15 \mathrm{~cm}$ & $15-30 \mathrm{~cm}$ & $0-15 \mathrm{~cm}$ & $15-30 \mathrm{~cm}$ & $0-15 \mathrm{~cm}$ & $15-30 \mathrm{~cm}$ & & \\
\hline \multicolumn{9}{|c|}{ Tillage crop establishment } \\
\hline$T_{1}$ & $28.3^{\mathrm{e}}$ & $26.6^{\mathrm{C}}$ & $2.49^{\mathrm{et}}$ & $2.26^{\mathrm{de}}$ & $185.2^{\mathrm{d}}$ & $176.3^{\mathrm{e}}$ & $578.5^{\mathrm{d}}$ & $461.6^{\mathrm{de}}$ \\
\hline$T_{2}$ & $30.6^{\mathrm{a}}$ & $28.9^{\mathrm{DC}}$ & $2.89^{\mathrm{de}}$ & $2.76^{\mathrm{cd}}$ & $242.1^{\mathrm{C}}$ & $231.0^{\mathrm{cd}}$ & $615.3^{\mathrm{cd}}$ & $506.7^{\mathrm{cd}}$ \\
\hline$T_{3}$ & $34.7^{\mathrm{ab}}$ & $32.8^{\mathrm{a}}$ & $4.08^{\mathrm{ab}}$ & $3.97^{\mathrm{a}}$ & $298.4^{\text {ab }}$ & $285.8^{\mathrm{a}}$ & $711.5^{\mathrm{ab}}$ & $624.8^{\mathrm{ab}}$ \\
\hline$T_{4}$ & $31.2^{\mathrm{cd}}$ & $29.1^{\mathrm{bc}}$ & $3.36^{\mathrm{cd}}$ & $3.21^{\mathrm{bc}}$ & $233.1^{\mathrm{C}}$ & $221.7^{\mathrm{d}}$ & $649.8^{\mathrm{bC}}$ & $563.5^{\mathrm{bC}}$ \\
\hline$T_{5}$ & $33.6^{\mathrm{bC}}$ & $31.6^{\mathrm{ab}}$ & $3.72^{\mathrm{bc}}$ & $3.58^{\mathrm{ab}}$ & $289.8^{\mathrm{D}}$ & $273.0^{\mathrm{bC}}$ & $674.9^{\mathrm{DC}}$ & $599.3^{0}$ \\
\hline$T_{6}$ & $36.9^{\mathrm{a}}$ & $34.8^{\mathrm{a}}$ & $4.49^{\mathrm{a}}$ & $4.32^{\mathrm{a}}$ & $308.1^{\mathrm{a}}$ & $295.8^{\mathrm{a}}$ & $775.4^{\mathrm{a}}$ & $683.2^{\mathrm{a}}$ \\
\hline$T_{7}$ & $23.4^{4}$ & $21.8^{\mathrm{d}}$ & $2.29^{1}$ & $2.08^{\mathrm{e}}$ & $135.0^{\mathrm{e}}$ & 128.5. & $507.6^{\mathrm{e}}$ & $411.6^{\mathrm{e}}$ \\
\hline \multicolumn{9}{|c|}{ Nutrient Management Practices } \\
\hline $\mathbf{F}_{1}$ & $16.7^{9}$ & $13.9^{g}$ & $1.53^{\dagger}$ & $1.05^{\mathrm{g}}$ & $288.3^{\mathrm{e}}$ & $100.7^{\mathrm{n}}$ & $329.3^{\text {n }}$ & $207.1^{\mathrm{n}}$ \\
\hline $\mathbf{F}_{2}$ & $20.1^{\text {tg }}$ & $16.8^{19}$ & $2.10^{\text {ef }}$ & $1.65^{\dagger}$ & $314.3^{\text {de }}$ & $155.2^{g}$ & $424.1^{g}$ & $245.2^{\text {tgh }}$ \\
\hline$F_{3}$ & $21.1^{\mathrm{ef}}$ & $18.2^{\mathrm{ef}}$ & $2.43^{\mathrm{de}}$ & $1.72^{\dagger}$ & $339.3^{\text {de }}$ & $184.1^{\mathrm{tg}}$ & $502.7^{\text {tg }}$ & $325.3^{\text {etg }}$ \\
\hline$F_{4}$ & $23.8^{\text {cde }}$ & $20.9^{\text {de }}$ & $3.29^{c}$ & $2.15^{\text {def }}$ & $529.2^{c}$ & $238.8^{\mathrm{de}}$ & $549.4^{\mathrm{ef}}$ & $363.3^{\mathrm{de}}$ \\
\hline$F_{5}$ & $24.7^{\text {cd }}$ & $22.9^{\text {cd }}$ & $3.49^{c}$ & $2.36^{\mathrm{de}}$ & $558.9^{\mathrm{bc}}$ & $267.4^{\text {cd }}$ & $595.3^{\mathrm{de}}$ & $398.4^{\text {de }}$ \\
\hline$F_{6}$ & $26.1^{\mathrm{bcd}}$ & $24.8^{\mathrm{bc}}$ & $3.76^{\mathrm{bC}}$ & $2.63^{\text {cd }}$ & $607.7^{\mathrm{bc}}$ & $294.8^{\mathrm{bc}}$ & $684.9^{\mathrm{cd}}$ & $469.1^{\mathrm{cd}}$ \\
\hline$F_{7}$ & $27.2^{\mathrm{bc}}$ & $25.2^{\mathrm{abc}}$ & $3.86^{b c}$ & $2.95^{\mathrm{bc}}$ & $649.8^{b c}$ & $315.8^{b}$ & $767.3^{\mathrm{bc}}$ & $565.7^{b c}$ \\
\hline$F_{8}$ & $29.2^{\text {ab }}$ & $27.7^{\mathrm{ab}}$ & $4.12^{\mathrm{ab}}$ & $3.45^{\mathrm{ab}}$ & $718.2^{\mathrm{ab}}$ & $389.1^{a}$ & $893.0^{a}$ & $675.0^{a}$ \\
\hline$F_{9}$ & $32.4^{\mathrm{a}}$ & $28.1^{\mathrm{a}}$ & $4.83^{\mathrm{a}}$ & $3.90^{\mathrm{a}}$ & $895.6^{\mathrm{a}}$ & $418.0^{\mathrm{a}}$ & $982.1^{\mathrm{a}}$ & $786.5^{\mathrm{a}}$ \\
\hline$F_{10}$ & $22.9^{\text {def }}$ & $19.4^{\mathrm{ef}}$ & $3.14^{\mathrm{cd}}$ & $1.95^{\mathrm{ef}}$ & $487.2^{\mathrm{cd}}$ & $210.1^{\mathrm{ef}}$ & $529.2^{\mathrm{ef}}$ & $342.9^{\mathrm{eft}}$ \\
\hline
\end{tabular}

WSOC $=$ Water soluble organic carbon, $\mathrm{BC}=$ Black carbon, $\mathrm{MBC}=$ Microbial biomass carbon,

$\mathrm{C}_{\min }=$ Mineralizable carbon

Table.5 Effect of different treatments on water footprints and water productivity on rice crop

\begin{tabular}{|c|c|c|c|c|c|c|c|c|c|}
\hline Treatments & $\begin{array}{l}\text { BWFP } \\
\left(\mathbf{m}^{3} \mathbf{t}^{-1}\right)\end{array}$ & $\begin{array}{l}\text { GWFP } \\
\left(\mathbf{m}^{3} \mathbf{t}^{-1}\right)\end{array}$ & $\begin{array}{c}\text { Gr WFP } \\
\left(\mathbf{m}^{3} \mathbf{t}^{-1}\right)\end{array}$ & $\begin{array}{l}\text { TWFP } \\
\left(\mathbf{m}^{3} \mathbf{t}^{-1}\right)\end{array}$ & $\begin{array}{c}\text { PERC_V } \\
\left(\mathrm{m}^{3} \mathbf{t}^{-1}\right)\end{array}$ & $\begin{array}{c}\text { TWU_V } \\
\left(\mathbf{m}^{3} \mathbf{t}^{-1}\right)\end{array}$ & $\begin{array}{l}W^{W} P_{\text {IRRI }} \\
\left(\mathrm{kg} \mathrm{m}^{-3}\right)\end{array}$ & $\begin{array}{l}\left(\mathbf{W P}_{\mathrm{TCW}}\right. \\
\left(\mathrm{kg} \mathrm{m}^{-3}\right)\end{array}$ & $\begin{array}{r}\text { WP } \\
\left(\mathbf{k g ~ m}^{-3}\right) \\
\end{array}$ \\
\hline \multicolumn{10}{|c|}{ Tillage crop establishment } \\
\hline $\mathrm{T}_{1}$ & $1705^{\mathrm{c}}$ & $105.8^{\mathrm{de}}$ & $2.4^{\mathrm{c}}$ & $1813^{\mathrm{de}}$ & $1320^{\mathrm{d}}$ & $3133^{d}$ & $0.53^{\mathrm{cd}}$ & $0.38^{\mathrm{de}}$ & $0.73^{\mathrm{ab}}$ \\
\hline $\mathbf{T}_{2}$ & $1650^{\mathrm{c}}$ & $109.5^{\mathrm{c}}$ & $1.9^{\mathrm{b}}$ & $1761^{\mathrm{cd}}$ & $1286^{\mathrm{cd}}$ & $3047^{\mathrm{cd}}$ & $0.55^{\mathrm{bc}}$ & $0.41^{\mathrm{c}}$ & $0.54^{\mathrm{d}}$ \\
\hline $\mathbf{T}_{3}$ & $1560^{b}$ & $111.9^{\mathrm{ab}}$ & $1.5^{\mathrm{a}}$ & $1673^{\mathrm{b}}$ & $1218^{b}$ & $2891^{b}$ & $0.57^{\mathrm{b}}$ & $0.47^{\mathrm{b}}$ & $0.41^{\mathrm{e}}$ \\
\hline $\mathbf{T}_{4}$ & $1670^{c}$ & $106.3^{\mathrm{d}}$ & $2.2^{\mathrm{c}}$ & $1779^{\mathrm{cd}}$ & $1295^{\mathrm{cd}}$ & $3074^{\mathrm{c}}$ & $0.51^{\mathrm{de}}$ & $0.40^{\mathrm{cd}}$ & $0.73^{\mathrm{ab}}$ \\
\hline$T_{5}$ & $1485^{\mathrm{ab}}$ & $110.7^{\mathrm{bc}}$ & $1.7^{\mathrm{ab}}$ & $1597^{\mathrm{ab}}$ & $1163^{\mathrm{ab}}$ & $2760^{\mathrm{ab}}$ & $0.61^{\mathrm{a}}$ & $0.54^{\mathrm{a}}$ & $0.64^{\mathrm{c}}$ \\
\hline$T_{6}$ & $1410^{\mathrm{a}}$ & $113.2^{\mathrm{a}}$ & $1.5^{\mathrm{a}}$ & $1525^{\mathrm{a}}$ & $1110^{\mathrm{a}}$ & $2635^{\mathrm{a}}$ & $0.64^{\mathrm{a}}$ & $0.56^{\mathrm{a}}$ & $0.46^{\mathrm{e}}$ \\
\hline $\mathbf{T}_{7}$ & $1878^{\mathrm{d}}$ & $104.9^{\mathrm{e}}$ & $2.7^{\mathrm{d}}$ & $1985^{\mathrm{e}}$ & $1385^{\mathrm{e}}$ & $3370^{\mathrm{e}}$ & $0.49^{\mathrm{e}}$ & $0.35^{\mathrm{e}}$ & $0.70^{\mathrm{b}}$ \\
\hline \multicolumn{10}{|c|}{ Nutrient Management Practices } \\
\hline $\mathbf{F}_{1}$ & $2054^{\mathrm{g}}$ & $105.1^{\mathrm{g}}$ & $2.8^{\mathrm{h}}$ & $2162^{g}$ & $1358^{\mathrm{e}}$ & $3520^{\mathrm{g}}$ & $0.29^{\mathrm{h}}$ & $0.24^{\mathrm{g}}$ & $0.77^{\mathrm{a}}$ \\
\hline $\mathbf{F}_{2}$ & $1968^{\mathrm{fg}}$ & $105.8^{\mathrm{fg}}$ & $2.7^{\mathrm{gh}}$ & $2077^{\text {fg }}$ & $1297^{\mathrm{de}}$ & $3374^{\mathrm{fg}}$ & $0.33^{\mathrm{g}}$ & $0.29^{\mathrm{f}}$ & $0.72^{\mathrm{a}}$ \\
\hline $\mathbf{F}_{3}$ & $1895^{\mathrm{ef}}$ & $106.4^{\mathrm{ef}}$ & $2.5^{\mathrm{fg}}$ & $2004^{\mathrm{ef}}$ & $1278^{\mathrm{d}}$ & $3282^{\mathrm{ef}}$ & $0.35^{\mathrm{g}}$ & $0.33^{\mathrm{e}}$ & $0.64^{\mathrm{b}}$ \\
\hline $\mathbf{F}_{4}$ & $1795^{\mathrm{cd}}$ & $108.6^{\mathrm{cd}}$ & $2.4^{\mathrm{def}}$ & $1906^{\mathrm{cd}}$ & $1210^{c}$ & $3116^{\mathrm{d}}$ & $0.41^{\mathrm{e}}$ & $0.38^{\mathrm{d}}$ & $0.61^{\mathrm{b}}$ \\
\hline $\mathbf{F}_{5}$ & $1760^{\mathrm{bcd}}$ & $109.4^{\mathrm{bc}}$ & $2.2^{\mathrm{cd}}$ & $1872^{\mathrm{bcd}}$ & $1195^{\mathrm{c}}$ & $3067^{\mathrm{cd}}$ & $0.47^{\mathrm{d}}$ & $0.46^{\mathrm{c}}$ & $0.54^{\mathrm{c}}$ \\
\hline$F_{6}$ & $1735^{\mathrm{bcd}}$ & $109.9^{b}$ & $2.1^{\mathrm{c}}$ & $1847^{\text {bcd }}$ & $1180^{\mathrm{c}}$ & $3027^{\mathrm{cd}}$ & $0.52^{\mathrm{c}}$ & $0.47^{\mathrm{c}}$ & $0.47^{\mathrm{d}}$ \\
\hline$F_{7}$ & $1709^{\mathrm{bc}}$ & $110.2^{b}$ & $1.8^{b}$ & $1821^{\mathrm{bc}}$ & $1105^{b}$ & $2926^{\mathrm{bc}}$ & $0.58^{b}$ & $0.54^{\mathrm{b}}$ & $0.41^{\mathrm{e}}$ \\
\hline $\mathbf{F}_{8}$ & $1682^{\mathrm{ab}}$ & $111.3^{\mathrm{a}}$ & $1.6^{\mathrm{ab}}$ & $1795^{\mathrm{ab}}$ & $1082^{\mathrm{ab}}$ & $2877^{\mathrm{ab}}$ & $0.61^{\mathrm{ab}}$ & $0.56^{\mathrm{ab}}$ & $0.37^{\mathrm{ef}}$ \\
\hline $\mathbf{F}_{9}$ & $1592^{\mathrm{a}}$ & $112.2^{\mathrm{a}}$ & $1.4^{\mathrm{a}}$ & $1706^{\mathrm{a}}$ & $1035^{\mathrm{a}}$ & $2741^{\mathrm{a}}$ & $0.63^{\mathrm{a}}$ & $0.59^{\mathrm{a}}$ & $0.33^{\mathrm{f}}$ \\
\hline$F_{10}$ & $1815^{\mathrm{de}}$ & $107.8^{\mathrm{d}}$ & $2.4^{\mathrm{de}}$ & $1925^{\mathrm{de}}$ & $1160^{c}$ & $3085^{d}$ & $0.37^{\mathrm{f}}$ & $0.41^{\mathrm{d}}$ & $0.63^{b}$ \\
\hline
\end{tabular}

Values in a column followed by the same letter are not significantly different $(\mathrm{P}<0.05)$.

$\mathrm{BWFP}=$ Blue water footprint, GWFP = green water footprint, Gr WFP = grey water footprint, TWFP = total water footprint, PERC_V $=$ Volume of percolation water, TWU_V $=$ Volume of total water use, $\mathrm{WP}_{\mathrm{IRRI}}=$ water productivity of irrigation applied, $\mathrm{WP}_{\mathrm{TCW}}=$ water productivity of total crop water need and $\mathrm{WP}_{\mathrm{ETC}}=$ water productivity as only evapo-transpiration.

\section{Conclusion}

The study indicated that application of RDF either through inorganic fertilization or through inorganic fertilizer $\mathrm{N}-\mathrm{P}-\mathrm{K}$ with $25 \%$ of nitrogen substituted by FYM with $\mathrm{K}$ sap in rice- wheat system improved the SOC, POC, MBC concentration and their sequestration rate. The SOC concentration and its sequestration were 
higher with the treatment applied with RDF partially substituted ( $25 \%$ on $\mathrm{N}$ basis) with organics $+\mathrm{k}$ sap than RDF application. Soil carbon sequestration with response to application of fertilizer partially substituted ( $25 \%$ on $\mathrm{N}$ basis) with organics were higher in zero till and raised beds with residue retention. Application of recommended dose of RDF or RDF partially substituted with organics has increased or maintained the system productivity. It is therefore important that the recommended fertilization either through inorganic fertilizer alone or in combination with manures plus $\mathrm{k}$ sap, and crop residue has to be promoted in order to maintain long-term rice-wheat system productivity. Nevertheless, there is a need for more quantitative assessment of the carbon sequestration potential of agricultural soils of IGP under different management practices for different soil types, climates and agricultural systems by supporting existing long term cropping system trial sites and the establishment of new ones where appropriate; quantifying interactions of SOC sequestration and developing soil carbon models that can account for locally relevant agricultural management practices.

\section{Acknowledgements}

This work was supported by Central Salt and Marine Research Institute, Bhavnagar, Gujarat on "Seaweed (K sap \& G sap) trials for different crops grown in western Uttar Pradesh" is gratefully acknowledged by the authors. We are grateful to the authorities of the Sardar Vallabbhai Patel University of Agriculture and Technology, Meerut, U.P., India for all support in execution of this experiment. We also acknowledge the technical support from. Moreover, we would like to express our great respect for the editors and anonymous reviewers to improve the manuscript quality.

\section{References}

Aiken, G.R., Mcknight, D.M. and Wershaw, R.L. (1985). Humic Substances in Soils, Sediment and Water: Geochemistry, Isolation and Characterization. New York: John Wiley \& Sons

Blair, G.J., Lefroy, R.D.B., Lisle, L. (1995). Soil carbon fractions based on their degree of oxidation, and the development of a carbon management index for agricultural systems. Aust. J. Agric. Res. 46, 14591466.

Blair, N., 2000. Impact of cultivation and sugar-cane green trash management on carbon fractions and aggregate stability for a chromic luvisol in Queensland, Australia. Soil Till. Res. 55, 183-191.

Chapagain, A.K. and Orr, S. (2009). An improved water footprint methodology linking global consumption to local water resources: a case of Spanish tomatoes. J Environ Manag 90, 1219-1228.

Dhir, R.P., Chaudhary, M.R., Nath, J., Somani, L.L. (1991). Constraints of sandy soils of arid and adjoining areas of Western and Northern India and their management. In: Biswas, T.D. (Ed.), SoilRelated Constraints in Crop Production, vol. 15. Indian Soc. Soil Sci., Bull., New Delhi, India, pp. 52-69.

Derpsch, R., Franzluebbers, A.J.,Duiker, S.W.,Reicosk, D.C., Koeller, K., Friedrich, T., Sá, J.C.M. and Weiss, K. 2014. Why do we need to standardize no-tillage research? Soil Till.Res.137, 16-22.

Dwivedi, S. K., Pal, A., Meshram, M. R. (2014). Effects of seaweed saps on soil health and productivity of potato (Solanum tuberosum L.). Current Adv Agri Sci. 6 (2): 133-137.

Gerbens-Leenes, P.W. and Hoekstra, A.Y. (2009).The water footprint of sweeteners and bioethanol from sugarcane, sugar beet and maize. Value of Water Research Report Series No. 38. UNESCO-IHE and University of Twente, Delft and Enschede, The Netherlands.

Gathala, M.K.,Kumara,V., Sharma, P.C., Saharawat, Y.S., Jat, H.S., Singh, M., Kumar,A., Jat, M.L.,Humphreys, E.,Sharma, D.K., Sharma, S.K. and Ladha, J.K. (2013). Optimizing intensive cereal-based cropping systems addressing current and future drivers of agricultural change in the northwestern Indo-Gangetic Plains of India. Agr. Ecosyst. Env. 177, 85-97.

Hammerbeck, A.L., Stetson, S.J., Osborne, S.L., Schumacher, T.E., Pikul Jr., J.L., (2012). Corn residue removal impact on soil aggregates in a notill corn/soybean rotation. Soil Sci Soc Am J. 4, 1390-1398.

Hanasaki, N., Inuzuka, T., Kanae, S. and Oki, T. (2010).An estimation of global virtual water flow and sources of water withdrawal for major crops and livestock products using a global hydrological model. $J$ Hydrology 384, 232-244.

Idso, S.B. and Idso, K.E. (2002). Global Warming, Carbon Sequestration to Mitigate. Ency-clop. Soil Sci., Marcel Dekker, New York, pp. 612-614.

Lal, R. (2004b). Soil carbon sequestration in India. Climatic Change 65, 277-296.

Latique S, Chernane $\mathrm{H}$, Mansori $\mathrm{M}$, El Kaoua M. (2013).Seaweed liquid fertilizer effect on physiological and biochemical parameters of bean plant (Phaseolus vulgaris variety paulista) under 
hydroponic system. Euro. Scient. J. 9 (30):174191.

Layek, J., Das, A., Ramkrushna, G. I., Trivedi, K., Yesuraj, D.,Chandramohan, M., Kubavat, D., Agarwal, P. K., Ghosh, A. (2015). Seaweed sap potential towards sustainable improvement of maize productivity: A dominant staple food crop of the North-east India. Int J. Environ Stud.72:305-315

Luo,Z.,Wang,E.and Sun,O.J. (2010).Canno-tillage stimulate carbon sequestration in agricultural soils? A meta-analysis of paired experiments. Agr. Ecosyst. Environ.139, 224-231.

Mohanty, D., Adhikary, S. P. and Chattopadhyay, G. N. (2013).Seaweed liquid fertilizer (SLF) and its role in agriculture productivity. The Ecoscan. Special issue. III: 147-155.

Mondal, D., Ghosh, A., Prasad, K., Singh, S., Bhatt, N., Zodape, S. T., Chaudhary, J. P., Chaudhari, J., Chatterjee, P. B., Seth, A.,Ghosh, P.K. (2015) .Elimination of gibberellin from Kappaphycus alvarezii seaweed sap foliar spray enhances corn stover production without compromising the grain yield advantage. Plant Growth Regulator. 75 (3): 657-666.

Naresh, R.K., Gupta, Raj K., Gajendra Pal, Dhaliwal, S.S, Kumar, Dipender, Kumar Vineet, Arya, Vichitra Kumar, Raju, Singh, S.P.,Basharullah and Singh,Onkar.(2015).Tillage crop establishment strategies and soil fertility management: resource use efficiencies and soil carbon sequestration in a rice-wheat cropping system. Eco. Env. \& Cons. 21:127-134

Post, W.M., Izarurralde, R.C., Jastrow, J.D., McCarl, B.A., Amonette, J.E., Bailey, V.L., Jardien, P.M., West, T.O., Zhou, J. (2004). Enhancement of car-bon sequestration in U.S. Soils Biosci. 54, 895-908,

Pramanick, B., Brahmachari, K. and Ghosh, A. (2014). Efficacy of Kappaphycus and Gracilaria sap on growth and yield improvement of seasame in new alluvial soil. J. crop and weed. 10 (1): 77-81.

Prasad, K., Das, A. K., Oza, M. D., Brahmbhatt, H., Siddhanta, A., Meena, R., Eswaran, K., Rajyaguru, M. R. and Ghosh, P. K. (2010). Detection and quantification of some plant regulators in a seaweed based foliar spray employing amass spectrometric technique sans chromatographic separation. J. Agri Food chemistry. 58: 45944601..

Shah, M. T., Zodape, S. T., Chaudhary, D. R., Eswaran, K., Chikara, J. (2013). Seaweed sap as an alternative liquid fertilizer for yield and quality improvement of wheat. J. Plant Nutrition. 36: 192-200.

Six J, Feller C, Denef K, Ogle SM, de Moraes JC, Albrecht A (2002) Soil organic matter, biota and aggregation in temperate and tropical soils- effects of no-tillage. Agronomie 22:755-775

Walkley A, Black IA (1934). An examination of the Degtjareff method for determining soil organic matter, and a proposed modification of the chromic acid titration method. Soil Sci 37:29-38

Wright, A.L., Dou,F.,Hons, F.M.2007.Soil organic C and $\mathrm{N}$ distribution for wheat cropping systems after 20 years of conservation tillage in central Texas. Agric. Ecosyst. Environ. 121, 376-382.

Yagi R, Ferreira ME, Cruz MCP, Barbosa JC (2005) Soil organic matter as a function of nitrogen fertilization in crop succession. Sci Agr 62:374380

Yan, D., Wang, D., Yang, L., (2007). Long-term effect of chemical fertilizer, straw, and manure on labile organic matter fractions in a paddy soil. Biology Fertility Soils 44, 93-101.

Zhang, J.J., Wang, L.B. and Li, C.L. (2010). Humus characteristics after maize residues degradation in soil amended with different copper concentrations. Plant Soil Environ. 56,120-124.

\section{How to cite this article:}

Naresh, R.K., Arup Ghosh, Vivak Kumar, R.K. Gupta, S.P. Singh, Purushottam, Vineet Kumar, Saurab Tyagi, Vikrant Singh, Nihal Chandra Mahajan, Arun Kumar and Onkar Singh. 2017. Tillage Crop Establishment and Organic Inputs with Kappaphycus - Sap Effect on Soil Organic Carbon Fractions and Water Footprints under a Six Year Rice-Wheat Rotation. Int.J.Curr.Res.Aca.Rev. 5(5), 57-69. doi: https://doi.org/10.20546/ijcrar.2017.505.008 